\title{
Probable reliability prediction of the dam constructed with ground materials of the Nam Chien hydraulic power system in Vietnam using the Monte Carlo method
}

\author{
Andrii Mozgovuy ${ }^{1, *}$, and Svitlana Butnik ${ }^{1}$ \\ ${ }^{1}$ Kharkiv National University of Construction and Architecture, 61002, Sumskaya Str., 40, \\ Kharkiv, Ukraine
}

\begin{abstract}
The current method of probabilistic safety assesses dams with ground material by the criterion of water overflow through the dam crest. Due to the stochastic nature of the material properties, loads and impacts method involves the use of the Monte Carlo method (statistical tests). The algorithm was tested on the example of the ground material dams of Nam Chien hydropower in the Vietnam.
\end{abstract}

Calculation and design of modern hydraulic engineering works require assessment of their reliability and safety on the basis of probabilistic methods. Quite a common type of water power systems backwater front structures are dams constructed of ground materials. In this paper, a modern method of probabilistic assessment of the reliability of dams constructed of ground materials is applied. The criterion of ensuring the edge state is water overflow over the dam crest. During the study of the dam reliability, the probabilistic nature of the loads and influences perceived by the dam is taken into account. Reliability assessment of the dam is fulfilled in the software complex Math Cad with the use of modern numerical Monte-Carlo method (statistical simulations method). The algorithm was tested on the example of the earthand-rockfill dam Nam Chien in Vietnam. The earth-and-rockfill dam is designed homogeneous with a clay soil core with upstream slope pavement using reinforced concrete $0.5 \mathrm{~m}$ thick slabs on a $0.4 \mathrm{~m}$ thick gravel layer. The slope base of the upstream slope is 1:1.1. From the downstream slope, topsoil ramping is carried. The slope base of the downstream slope is 1:1.2. (Fig. 1).

The analysis of literary sources [1-10] shows that the statistical simulations method is the most convenient to perform calculations to assess the probability of water overflow over the dam crest.

According to the Monte Carlo method, $N$ simulations are performed. The sequence of calculations for each simulation is accepted as follows.

1. Water level marks in front of the dam $P_{Q}$ are given by evenly distributed random probability in the range from 0 to 1 , caused by the maximum flood flow.

2. The quantile is determined by the value of $P_{Q}$, - the mark of the static water level in front of the dam $Z_{Q}$ caused by the maximum flood flow, according to the relation $Z_{Q}$

${ }^{*}$ Corresponding author: mozgovoyandrey@i.ua 


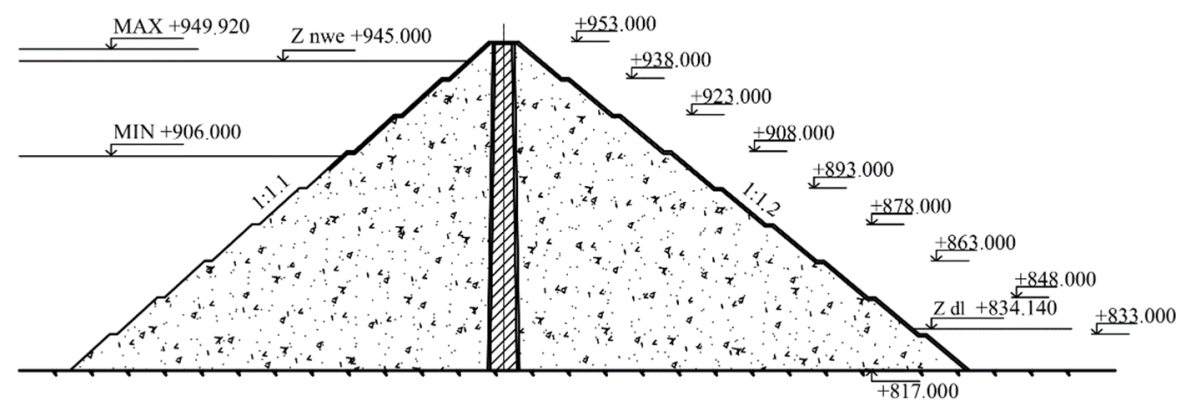

Fig. 1. The section of the earth-and-rockfill dam of the hydraulic power system Nam Chien

3. Due to the well-known mark $Z_{Q}$ the values of the fetch $L$ and the average water depth in the reservoir $\mathrm{H}$ are found, using well-known relations $L=L\left(Z_{Q}\right), H=H\left(Z_{Q}\right)$.

4. Wind speed $P_{V}$ is given by evenly distributed random probability in the range from 0 to 1 .

5. The quantile is determined by the value of $P_{V}$ - wind speed $V$.

6. Using the normative technique based on the known values of fetch $L$, the average water depth in the reservoir $H$ and wind speed $V$, the wave parameters are calculated.

6.1. The average wave height is found.

6.2. Average wave periods are calculated.

6.3. The average wave length is determined.

6.4. The wave length $1 \%$ of exceedance probability in the wave system is calculated.

6.5. The height of wave run-up on the slope is determined.

6.6. The wind setup height is found.

7. The water level mark in front of the dam $Z$ is determined.

8. The fulfillment of the condition $Z<Z_{d c}$ is checked.

According to the numerical experiment program, the planned number of statistical simulations was carried out. The number of statistical simulations, in which the condition that the water level elevation in front of the dam would be less than the earth dam crest mark was not fulfilled, was attributed to the total number of simulations and determined the probability of the risk of water overflow over the dam crest.

After performing all $N$ simulations, the probability of water overflow over the dam crest $\mathrm{P}_{\mathrm{OVT}}$ is calculated as the ratio of the number of simulations $N_{l}$, with $Z_{u l}<Z_{d c}$, to the number of all simulations $N$.

It should be noted that due to the smallness of the values $R_{O V T}$, the number of statistical simulations should be relatively larger in order to provide sufficient probability of the derived values.

To determine the risk of water overflow over the earth dam crest, random probability of wind speed $p V$ is set distributed from 0 to 1 (see Fig. 2). According to the outcoming data, the probabilities of annual maximum wind speed can be represented by a normal distribution.

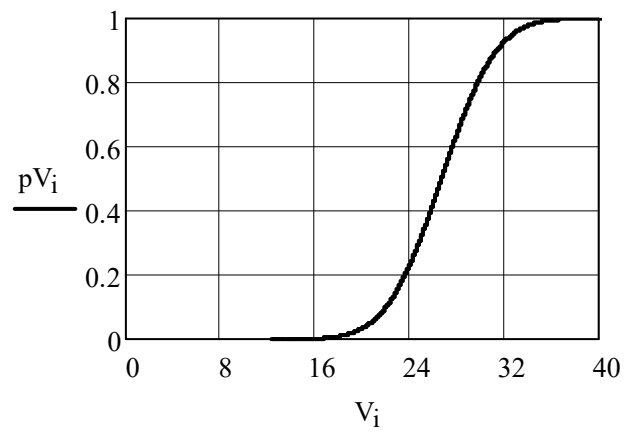


Fig. 2. The maximum wind speed $\mathrm{V}$ distribution probabilistic curve, $\mathrm{m} / \mathrm{s}$, in the geographical location of the Nam Chien dam

The quantile is determined by the value of $P_{V}$ - wind speed $V$.

Random probability $p Z$ of water level mark $Z$ in front of the dam constructed of ground materials is set, distributed from 0 to 1 , m (see Fig. 3).

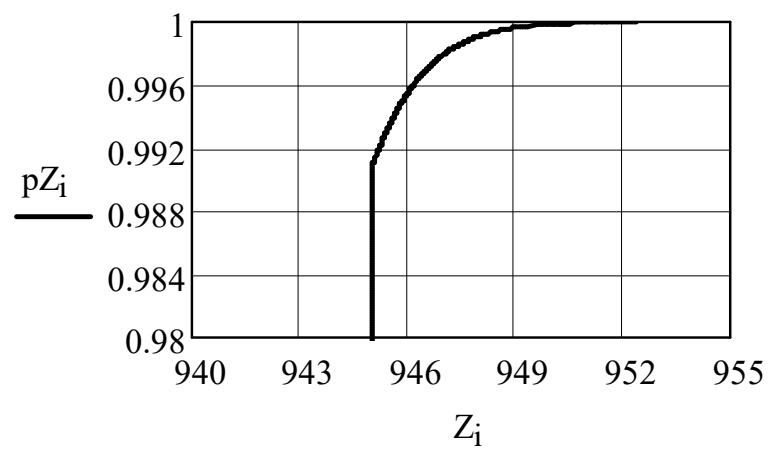

Fig. 3. Probabilistic curve of the static water level distribution in front the dam constructed of ground materials $Z, m$ Nam Chien dam

At the same time, the static water level is caused by the maximum flood flow.

The quantile is determined by the value of $p Z$ - the water level mark $Z, \mathrm{~m}$ in front of the dam constructed of ground materials.

Depending on static water level Z, m, average value of the water depth in the reservoir $H, \mathrm{~m}$ and water depth in the reservoir $H s, \mathrm{~m}$, in front of the earth dam are determined (see Fig. 4).

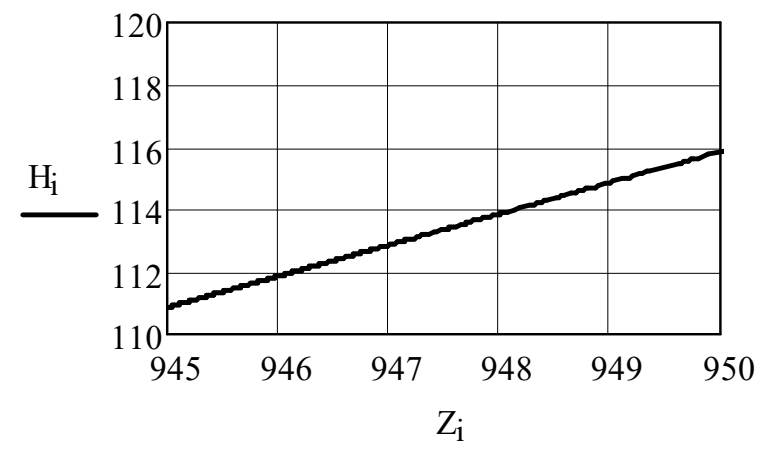

Fig. 4. Relation between the average value of water depth in the reservoir $\mathrm{H}, \mathrm{m}$ and the static water level mark Z, m

Depending on the average water depth in the reservoir $H, \mathrm{~m}$ the fetch $L$ is determined, $\mathrm{m}$.

Depending on fetch $L, \mathrm{~m}$, water depth in the reservoir Ns, $\mathrm{m}$ in front of the dam and wind speed $V, \mathrm{~m} / \mathrm{s}$, wind setup height $d h, \mathrm{~m}$ (see Fig. 5) is determined according to the known formula 1 :

$$
d h=(0.3+0.09 \times V) \times 10^{-6} \frac{V^{2} \times L}{g \times H_{C}} \times \cos \left(\alpha_{W}\right),
$$

where 0.3 and 0.09 - empirical coefficients, $g$ - gravitational acceleration, $\mathrm{m} / \mathrm{s}^{2}, \alpha_{w}-$ the angle between the longitudinal axis of the reservoir and the airflow direction. 


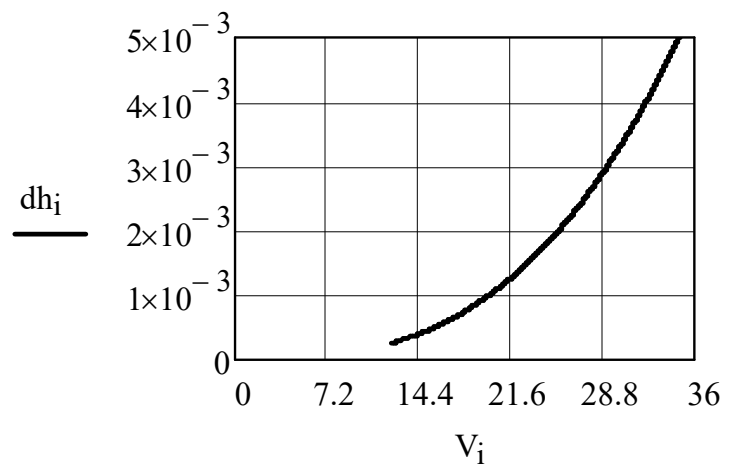

Fig. 5. Relation between the wind setup height $\mathrm{dh}, \mathrm{m}$ in the reservoir $H, \mathrm{~m}$ and the wind speed $V, \mathrm{~m} / \mathrm{s}$

Depending on fetch $L, \mathrm{~m}$, water depth in the reservoir $N, \mathrm{~m}$ in front of the dam and wind speed $V, \mathrm{~m} / \mathrm{s}$, average wave height $h_{a v}, \mathrm{~m}$ (see Fig. 6) is determined according to the formula 2:

$$
h_{a v}=0.16 \frac{V^{2}}{g}\left[1-\left[1+0.006 \sqrt{g \frac{L}{V^{2}}}\right]^{-2}\right] \times \operatorname{th}\left[\frac{0.625\left[g \frac{H}{V^{2}}\right]^{0.8}}{1-\left[1+0.006 \sqrt{g \frac{L}{V^{2}}}\right]^{-2}}\right],
$$

where $0.006,0.16,0.625$ - empirical coefficients.

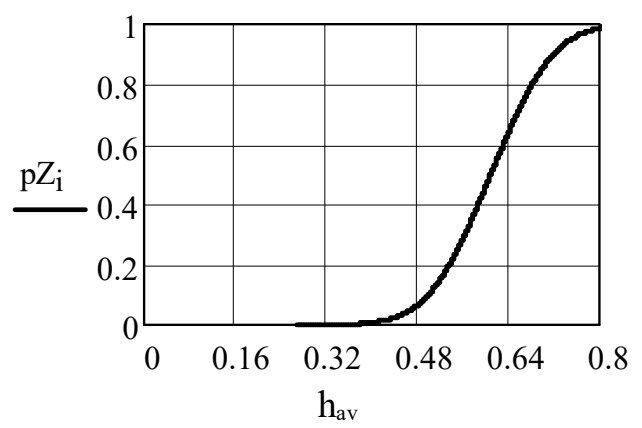

Fig. 6. Relation between the average wave height $h_{a v}, m$ in the reservoir $H, m$ and the random value the static water level mark $Z, \mathrm{~m}$

Depending on average wave height $h_{a v}, \mathrm{~m}$ and wind speed $V, \mathrm{~m} / \mathrm{s}$, average wave period $T_{a v}$ is determined using formula 3 :

$$
T_{a v}=3.1 \times 2 \pi \frac{V}{g}\left[g \frac{h_{a v}}{V^{2}}\right]^{0.625},
$$

where $0.625,3.1$ - empirical coefficients.

Depending on average wave period $T_{a v}$, average wave length $\lambda_{a v}, \mathrm{~m}$ is determined using formula 4:

$$
\lambda_{a v}=\frac{g \times T_{a v}^{2}}{2 \pi}
$$


Depending on fetch $L, \mathrm{~m}$, wind speed $V, \mathrm{~m} / \mathrm{s}$, and average wave length $h_{a v}, \mathrm{~m}$, the wave length $1 \%$ of exceedance probability in the wave system is determined using formula 5 :

$$
h_{1 \%}=h_{a v} \frac{(-\ln (0.01)) \times 0.001\left[\sqrt{g \frac{L}{V^{2}}}+390\right]}{G\left[0.001\left[\sqrt{g \frac{L}{V^{2}}}+390\right]+1\right]},
$$

where $0.001,1,390$ - empirical coefficients; 0.01 - wave height exceedance probability; $G$ value of the gamma-function.

Depending on the wave height $1 \%$ of exceedance probability in the wave system $\mathrm{h}_{1 \%}, \mathrm{~m}$ the wave run-up on the slope $h_{\text {run } 1 \%}, \mathrm{~m}$ is determined according to the formula 6 :

$$
h_{r u n 1 \%}=k_{r} \times k_{p} \times k_{s p} \times k_{r u n} \times h_{1 \%}
$$

where $k_{r}$ - coefficient of slope paving roughness; $k_{p}$ - coefficient of slope paving penetration; $k_{s p}$ - coefficient, which depends on wind speed and slope ratio; $k_{r u n}$ coefficient, which is determined using formula 7:

$$
k_{r u n}=1,2 \times \cos \alpha \times \sqrt{\frac{\lambda}{h_{1 \%} \times\left(1+\operatorname{ctg}^{2} \phi\right)}},
$$

where $\alpha$ is the angle between the wave line and the normal line to the bank line; $\varphi$ - canting angle of the slope.

Depending on the water level mark $\mathrm{Z}, \mathrm{m}$, the height of wave run-up on the slope $\mathrm{h}_{\text {run } 1 \% \text {, }}$ $\mathrm{m}$ and the wind setup height $\mathrm{dh}, \mathrm{m}$ the water level mark in front of the dam $Z_{\mathrm{f}}, \mathrm{m}$ is determined using formula 8 (see Fig. 7):

$$
Z_{f}=Z+h_{r u n 1 \%}+d h
$$

The fulfillment of the condition 9 is checked

$$
Z_{f}<Z_{D C}
$$

where $Z_{D C}$ is the mark of the earth dam crest.

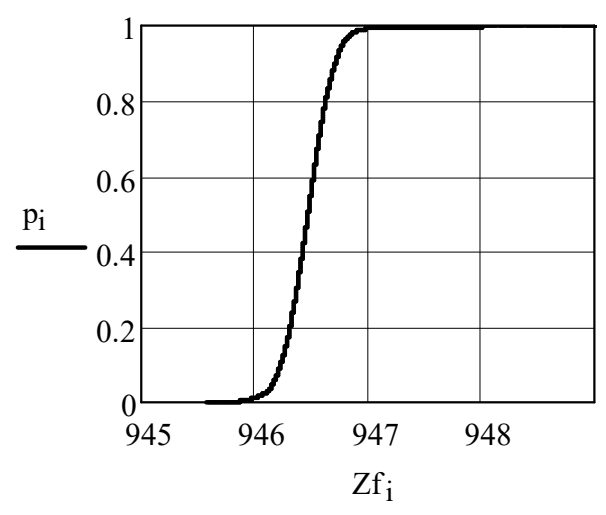

Fig. 7. Probabilistic curve of the water level mark distribution in front the dam constructed of ground materials $Z_{f}$, $m$ of the hydraulic power system Nam Chien 
Calculation of the earth-and-rockfill dam of the hydraulic power system Nam Chien under the condition of preventing the water overflow over the crest was carried out according to the normative method for the first and for the second settlement cases.

The results of the calculations of the earth-and-rockfill dam of the hydraulic power system Nam Chien under the condition of preventing the water overflow over the crest carried out according to the normative method for the first settlement case are given in Table 1, for the second settlement case - in Table 2, the results of the probabilistic calculations of the earth-and-rockfill dam - in Table 3.

Table 1. The results of calculations of the earth-and-rockfill dam of the hydraulic power system Nam Chien under the condition of preventing the water overflow over the crest was carried out according to the normative method for the first settlement case

$\left.\begin{array}{|c|c|c|}\hline \text { No. } & \text { Name of the estimated grandeur in } & \text { Value } \\ \hline 1 & \text { Normal water surface elevation } Z_{N W E}, \mathrm{~m} & 945.0 \\ \hline 2 & \begin{array}{c}\text { Maximum rated wind speed } V, \mathrm{~m} / \mathrm{s} 2 \% \text { of exceedance } \\ \text { probability }\end{array} & 35.19 \\ \hline 3 & \text { Average value of water depth in the reservoir } H, \mathrm{~m} & 110.86 \\ \hline 4 & \text { Water depth in the reservoir } H c, \mathrm{~m} \text { in front of the dam } & 127.0 \\ \hline 5 & \text { The fetch } L, \mathrm{~m} & 1500 \\ \hline 6 & \text { Wind tide height } d h, \mathrm{~m} & 4.757 \cdot 10^{-3} \\ \hline 7 & \text { Average wave height } h_{a v}, \mathrm{~m} & 0.787 \\ \hline 8 & \text { Average wave period } T_{a v}, \mathrm{~s} & 2.944 \\ \hline 9 & \text { Average wave length } \lambda_{a v}, \mathrm{~m} & 13.533 \\ \hline 10 & \text { Wave height } 1 \% \text { of exceedance probability in the wave } \\ \text { system } h_{1 \%} \mathrm{~m}\end{array}\right)$

Table 2. Results of calculations of the earth-and-rockfill dam of the hydraulic power system Nam Chien under the condition of preventing the water overflow over the crest was carried out according to the normative method for the second settlement case

$\left.\begin{array}{|c|c|c|}\hline \text { No. } & \text { Name of the calculated values } & \text { Value } \\ \hline 1 & \text { Maximum water surface elevation } Z_{M W E}, \mathrm{~m} & 949.92 \\ \hline 2 & \begin{array}{c}\text { Maximum rated wind speed } V, \mathrm{~m} / \mathrm{s} 20 \% \text { of exceedance } \\ \text { probability }\end{array} & 29.77 \\ \hline 3 & \text { Average value of water depth in the reservoir } H, \mathrm{~m} & 115.78 \\ \hline 4 & \text { Water depth in the reservoir } H c, \mathrm{~m} \text { before the dam } & 131.92 \\ \hline 5 & \text { The fetch } L, \mathrm{~m} & 1510 \\ \hline 6 & \text { Wind tide height } d h, \mathrm{~m} & 3.082 \cdot 10^{-3} \\ \hline 7 & \text { Average wave height } h_{a v}, \mathrm{~m} & 0.684 \\ \hline 8 & \text { Average wave period } T_{a v}, \mathrm{~s} & 2.792 \\ \hline 9 & \text { Average wave length } \lambda_{a v}, \mathrm{~m} & 12.176 \\ \hline 10 & \text { Wave height } 1 \% \text { of exceedance probability in the wave } \\ \text { system } h_{1 \%}, \mathrm{~m}\end{array}\right)$


Table 3. The results of probabilistic calculations of the earth-and-rockfill dam

\begin{tabular}{|c|c|c|c|c|}
\hline $\begin{array}{c}\text { CC } \\
\text { consequ } \\
\text { ence } \\
\text { class) }\end{array}$ & $\begin{array}{c}\text { Number of } \\
\text { statistical } \\
\text { tests } \\
\text { probability of water } \\
\text { overflow over the crest, } \\
\text { year }\end{array}$ & $\begin{array}{c}\text { Estimated value of the } \\
\text { Confidence } \\
\text { interval, } \\
\text { year }{ }^{-1}\end{array}$ & $\begin{array}{c}\text { Accepted } \\
\text { value of the } \\
\text { probability of } \\
\text { water } \\
\text { overflow over } \\
\text { the crest, year- } \\
1\end{array}$ \\
\hline \multicolumn{4}{|c|}{ The earth-and-rockfill dam of the hydraulic power system Nam Chien } \\
\hline CC3 & $1 \cdot 10^{6}$ & $2 \cdot 10^{-5}$ & $\begin{array}{c}1.66 \cdot 10^{-5}- \\
1.83 \cdot 10^{-5}\end{array}$ & $5 \cdot 10^{-5}$ \\
\hline
\end{tabular}

\section{Conclusions}

According to the probabilistic assessment of the dam of the hydraulic power system Nam Chien, it may be concluded that the probability of water overflow over the crest of the dam $p_{\text {est. }}=2 \cdot 10^{-5}$ and it does not exceed the accepted value of $p_{a c c .}=5 \cdot 10^{-5}$, and the reliability of the earth-and-rockfill dam is provided.

\section{References}

1. N.S. Arunraj, S. Mandal, J. Maiti, Acc. An. \& Prev. 55, 242-255 (2013)

2. L. Altarejos-García, I. Escuder-Bueno, A. Serrano-Lombillo, M.G. Membrillera-Ortuño, Struc. Saf. 36-37, 1-13 (2012)

3. O. Morales-Nápoles, D.J. Delgado-Hernández, D. De-León-Escobedo, Arteaga-Arcos, Struc. Infr. Eng. 10, 589-603 (2014)

4. L. Peyras, C. Carvajal, H. Felix, C. Bacconnet, P. Royet, J.P. Becue, D. Boissier, Eur. J Env. Civ. Eng. 16, 795-817 (2012)

5. Z.Y. Wu, Y.L. Li, J.K. Chen, H. Zhang, L. Pei, Comp. Geot. 51, 42-49 (2013)

6. Y. Li, Y. Sun, B. Li, Z. Xu, Comp. Geot. 81, 19-25 (2016)

7. A.O. Mozgovuy, Naukovii visnyk budivnitstva, 54, 272-277 (2009)

8. A.O. Mozgovuy, Naukovii visnyk budivnitstva, 58, 264-270 (2010)

9. A.O. Mozgovuy, Naukovii visnyk budivnitstva, 65, 364-370 (2011)

10. S.V. Butnik, K.S. Belousova, Naukovii visnyk budivnitstva, 68, 132-137 (2012) 